\title{
Why have Anti-Offshore Tin Mining Movements Failed in Bangka but Succeeded in East Belitung? Political Opportunity Structures and Political Settlement in the Context of Indonesia's Democratic Future
}

\author{
Eko Bagus Sholihin
}

Received: 13 May 2020 | Accepted: 15 March 2021 | Published: 20 March 2021

\begin{abstract}
Civil society movements have occupied an important position in Indonesia's democratisation. This article seeks to determine why anti-offshore tin mining movements in the post-authoritarian era failed in Bangka but succeeded in East Belitung, an area where tin mining has historically been important. By analysing the political opportunity structures and political settlement mechanisms involved, this article argues, first, that the movement's success in East Belitung can be attributed to open political access, fragmentation within elite circles, and alliances with influential elites; such political opportunities were not available in Bangka. Second, in Bangka, the local bourgeoisie and brokers used clientelistic approaches in their political settlement and prevented resistance by co-opting local communities within the extraction chain. In East Belitung, meanwhile, such efforts were stymied by the lack of local bourgeoisie, the strength of environmental awareness, and the availability of alternative economic resources. It may thus be concluded that, while a clientelistic approach to settlement may prevent conflict, it also limits the political participation of civil society movements - an important element of democracy.
\end{abstract}

Keywords: Resistance movements; political opportunity structures; political settlement; offshore tin mining; Bangka Belitung

Introduction

Since the fall of Suharto's authoritarian regime, Indonesia's transition to democracy has coincided with the rise of local resistance movements and increased conflict. Since the late 2000s, ethnic violence has given way to widespread conflict over natural resources (Diprose, 2008). Such conflicts are often triggered by

\footnotetext{
${ }^{1}$ The author is a lecturer at the Department of Political Science, Faculty of Social and Political Science, Raden Fatah State Islamic University, Palembang, Indonesia. Email: ekobagussholihin@gmail.com
} 
the arrival of extractive industries, which stimulate land disputes and opposition to mining activities (Diprose \& Azca, 2020; Manalu, 2007; Situmorang, 2013).

One major driver of conflict over natural resources in post-authoritarian Indonesia has been anomalies in its democratisation process. The country's democratisation has resulted in the duplication of local predatory elites, who have co-opted democracy for their own purposes. Through patronage and clientelism mechanisms, those who have access to natural resources remain capable of strategically influencing policy (Aspinall, 2011). Although clientelism in political and economic structures varies in form and level from region to region, as a rule it is generally used to ensure that political and economic power structures advance elite interests rather than the common good. As such, extractive activities often face resistance (Aspinall, 2011).

Elsewhere, political scientists have argued that civil society movements, which serve a social control function, have proven a breath of fresh air for democratisation (Della Porta, 2013). In linking resistance movements with democratisation, the political process approach-as well as its political opportunity structure (POS) concept-has been particularly popular (McAdam, 1996). According to this concept, it is political structures-rather than internal factors-that shape the rise, structure, scope, and success of movements (McAdam, 1996; Wahlstrom, 2016).

Reflecting on the political and economic structures of post-authoritarian Indonesia, it is apparent that increased political openness has coincided with the rise of clientelism in and conflict over resource extraction. As such, this article explores the dynamics of resistance movements in democratic Indonesia and said movements' power relations with formal/informal institutions in the extractive sector. More specifically, this article seeks to determine why resistance movements in East Belitung were more extensive and successful in opposing offshore mining than similar movements in nearby Bangka.

Both Bangka and Belitung have strong historical ties with tin extraction (Erman, 2009). However, while offshore mining has become widespread in Bangka, it remains scarce in Belitung. When plans to commence offshore in East Belitung were announced to the public in 2016, they faced heave resistance from local fishermen and residents (Ibrahim et al., 2018; Diprose et.al., 2020) As of 2020, resistance movements have successfully blocked offshore tin mining in East Belitung. Conversely, resistance movements were less widespread in Bangka. If the social, economic, and environmental impact of such extraction was equally detrimental in both areas, why was resistance less extensive in Bangka? This question will be answered herein, leaning on two key concepts: political opportunity structures and political settlement.

In its analysis of resistance movements in Bangka-Belitung, this article's theoretical contribution lies in its operationalisation of the political opportunity structures (POS) concept within the framework of Indonesia's local politics. In the literature on political processes in Indonesia, POS are commonly defined as democratic and open configurations of the political system that 
provide the public with more opportunities to participate in local politics and influence policy (Manalu, 2007). Such a definition views POS as a national project, one that began with Reformasi in 1998. By operationalising the definition of POS offered by Sidney Tarrow (1996), this article returns to Eisinger (1973) and his emphasis on the local dimensions of POSdimensions that have often been neglected in analysis (Heidjen, 1997; Heidjen, 2006; Manalu, 2007; Wahlstrom, 2006; Clayton, 2018; Gomza \& Zajaczkowski, 2019). Political and economic structures vary from region to region, and this affects the characteristics and achievements of local resistance movements.

This article also seeks to explore the future of narrow political settlement, answering the question posed by Diprose and Azca (2020): what will happen to political settlement when brokers fail, and what will happen when the environmental consequences of natural resource extraction are so extreme that potential benefits are deemed insignificant? (Diprose \& Azca, 2020). In this article, the economic and political dynamics of the extractive industries in Bangka will be used to represent a narrow political settlement (clientelist political settlement) that has succeeded, while those in Belitung will be used to represent one that failed.

Finally, and practically, this article employs a comparative methodespecially in its analysis of political settlement. Studies of tin mining in Bangka and Belitung are commonplace, as are studies of related conflicts (Harahap, 2012; Erman, 2010; Zulkarnain, 2005; Indra, 2014; Zulkarnain, 2018; Ibrahim et al, 2018; Nugraha, 2020). However, no such studies have employed a comparative approach, even though such an approach offers a beneficial means of identifying the particular social, political, cultural, and economic characteristics of areas with similar natural resources, distinguishing between these areas, ascertaining when and how differences emerged, and understanding how these differences influence local communities' specific responses to resource extraction.

\section{The Future of Democratisation: Rediscussing Political Opportunity Structures, Political Settlement, and Social Movements at the Local Level}

In the literature on social movements, it is commonly concluded that successful movements originate from the financially disadvantaged and socio-culturally marginalised, and that they are made possible by democratic political practices (Fishman, 2017). In other words, democracy is commonly perceived as providing ideal conditions for social movements to rise and thrive. At the same time, social movements are recognised as contributing importantly to the democratisation process (McAdam, 1996). In the political process approach, democracy is understood as an opportunity structure. As argued by Gamson and Meyer (1996), democracy provides social movements with the opportunity to access channels for political protest; at the same time, social movements contribute to the creation of democracy.

Although the reciprocal relationship between POS and social movements was most popular amongst political process scholars, this approach remains relevant today. Worldwide, urban social movements have mushroomed at the local level, 
embracing a range of issues and establishing transnational and international networks. The availability of political access, thus, may be supplemented by another variable: access to technology (Domaradzka, 2018). Consequently, technology may be considered a new instrument for analysing POS, one absent from the studies undertaken by Brockett (1991), Kriesi et al. (1992), Tarrow (1994), and McAdam (1996), almost three decades ago.

Given the strengthening of transnational and international ties between social actors and local regulators in recent years, it is becoming increasingly important to employ a dynamic analysis that reaches beyond the national. For example, the transnational environmentalist movement Friends of the Earth has urged global media (The Guardian, BBC, and $\mathrm{CNN}$ ) and global electronic companies to pressure local regulators and extractive industries to implement a sustainable tin supply chain in Bangka-Belitung (Diprose et al., 2020). Such global pressure on regulators and local industries has shaped the specific political and economic characteristics of local actors, underscoring the power of local and global interactions. This underscores the importance of employing the POS concept for local-level analysis.

Over the course of Indonesia's democratisation and decentralisation, one authority that has been delegated to local governments is the authority to issue extraction permits (Diprose \& Azca, 2020). This has significantly transformed local political and economic power structures throughout the country, and each area has developed its own specific economic and political structures that reflect its unique socio-historical, economic, and geographical conditions.

At the same time, decentralisation has intensified competition between local actors in their efforts to control the distribution of resources and related benefits (Diprose \& Azca, 2020). McCarthy (2004) argues that decentralisation has created an unstable socio-legal configuration, and this implies conflict in the natural resource sector. In BangkaBelitung, the liberalisation and deregulation of tin policy since 1999 has created a tugof-war between the central, provincial, and regency governments, as well as conflicts of interest between local communities, entrepreneurs, and governments (Zulkarnain, 2005). As such, political settlement is necessary to prevent potential conflict.

Understanding the mechanisms of political settlement, and the specific effects of said mechanism, is thus important. In Riau, political settlement has been realised through narrow and exclusive means, i.e. by increasing local governments' share of the profits while simultaneously increasing elite brokers' control by allowing them to distribute benefits amongst residents involved in the extraction chain. Such settlement and brokerage not only stifled potential separatist movements, but also prevented conflict over natural resources in Riau (Diprose \& Azca, 2020). We ask, however, what happens when elites and brokers fail to distribute their profits, or when external factors (such as environmental considerations) result in continued opposition? In the democratisation process, is it better when civil society movements are controlled through narrow and exclusive approaches to political 
settlement, or when said movements have access to broader and more inclusive approaches? This study's novelty and contribution to the politics of settlement in Indonesia thus stems from its answer to this question.

\section{Political Opportunity Structures and Political Settlement}

This article employs two concepts: political opportunity structures and political settlement. These concepts, used in conjunction, provide a means of ascertaining why the anti-offshore mining movement succeeded in East Belitung but failed in Bangka. The author's decision to use these two concepts in conjunction will be explained below.

Social movements-including their motivations, goals, targets, strategies, and tactics-do not exist within a vacuum. Activists' knowledge, creativity, and activities can only be understood and evaluated by considering the political structures that determine the rules of the game (Meyer, 2004). It is this assumption that underpins the concept of political opportunity structures, as well as said concept's application in examining social movements (Heijden, 2006).

As a concept, POS was first introduced by Eisinger (1973), who used it to analyse the extent of unrest in forty-three cities in the United States. He found that protests were most prominent in cities that employed a mixed political system-open and closed simultaneously (Eisinger, 1973, in Heijden, 2006). Eisinger thus defined POS as "the degree to which groups are likely to be able to gain access to power and to manipulate the political system" (McAdam, 1996). Interest groups' ability to manipulate the political system is strongly informed by said system's openness. As argued by Kitschelt (1986), the inclusiveness (or exclusiveness) of political structures is informed by the number of political parties, the independence of legislative institutions, and the presence of intermediates (Kitschelt, 1986, in Heijden, 2006).

After reviewing these definitions, the author reviewed the elements that enable POS to function. No fewer than four scholars have sought to identify the operational dimensions of such structures: Brockett (1991), Kriesi et al. (1992), Rucht (1989), and Tarrow (1994). In this article, the author will borrow the dimensions offered by Tarrow (1994), i.e. the inclusivity/exclusivity of political access, the existence of elite fragmentation, and the ability to establish alliances with elites (Tarrow, 1994, in McAdam, 1996; Heijden, 2006; Gomza \& Zajaczkowski, 2019).

POS has become known for its highly inclusive operational dimensions (Heijden, 2006), and McAdam (1996) argues that this inclusivity has dulled its analytical edge and invited misinterpretation. To avoid such problems, this article uses the three dimensions offered by Tarrow (1994): political access (open/closed), degree of elite fragmentation (fragmented/ consolidated), and alliances with elites (existent/non-existent) (Heijden, 2006). All are relevant to the case of BangkaBelitung, and all would contribute to this article's analysis of POS and its influence on the success of resistance movements in the area.

This study's second theoretical pillar is the concept of political settlement, which is used to analyse the power relations between social movements and their 
competitors (i.e. state and private sector actors) in resource conflict as well as the power relations between state actors and extractive industries (Bebbington, 2015, in Winanti, 2020). By employing this concept, POS' inability to recognise the influence of informal actors (local bourgeoisie and brokers) on formal institutions' policymaking will be mitigated. POS lacks the tools necessary to explain how informal actors influence government actors' agenda setting, thereby ensuring that their own interests are advanced.

Scholars' use of political settlement stems from their concern for local political and economic elites' ability to maintain power and advance their specific interests by co-opting formal institutions, and the skill with which they do so (Di John \& Putzel, 2009, in Winanti et al., 2020). Di John (2009) defines political settlement as "the balance or distribution of power between contending social groups and social classes, on which any state is based" (Di John \& Putzel, 2009, in Winanti et al., 2020). Key to its analysis, thus, is an understanding of how power is distributed and how those in power compete to control the distribution of resources (Khan, 2010). Political settlement is achieved when profit-sharing mechanisms are approved and supported by the institutions that distribute power in society, thereby enabling said institutions to endure, to create political stability, and to minimise conflict-albeit sometimes without political justice or inclusiveness (Diprose \& Azca, 2020)

In the context of post-authoritarian Indonesia, political settlement is often associated with power contention and efforts to control the distribution of profits from the extractive sector. It has emerged within a context where many are economically and politically reliant on the extraction of natural resources (Winanti, 2020). Power is created not through the structural distribution of social and economic power, but rather through elite alliances' competition to control the distribution of the extractive sector's economic and political benefits (Diprose et al., 2020 in Winanti et al., 2020)

Khan (2010) identifies four types of political settlement, with the two most relevant for this discussion being capitalist political settlement and clientelist political settlement. Capitalist political settlement refers to situations where power is wielded by formal institutions and by individuals who enjoy legal ownership. It is characterised by impersonal compliance mechanisms (following "rules of the game" rather than personal rules), and by formal institutions wielding power that is legally bestowed upon them (Khan, 2010). Such capitalist political settlement is generally found in developed countries, where it is realised using an inclusive, coordinated, and impersonal approach (Kelsall, 2016).

Conversely, clientelist political settlement relies on personal compliance mechanisms (patronage and clientelism). In this form of political settlement, power is generally wielded by non-formal institutions, who use paternalistic mechanisms to control access to the distribution of natural resources and related benefits. Generally, they do so in direct opposition to formal institutions and regulations (Khan, 2010). Clientelist political settlement-characterised as exclusive, spoils-driven, and personalisedis most common in developing and authoritarian countries (Kelsall, 2016). 
Considering both forms of political settlement is necessary when comparatively analysing the distribution of natural resources in Bangka-Belitung. Reflecting Diprose and Azca (2020), who found that the application of narrow political settlement in Riau limited the rise of separatist movements, this article argues that clientelist political settlement was used by Bangka's local bourgeoisie and brokers to curtail the growth of the antioffshore mining movement. Conversely, in Belitung, the rise and ultimate success of the anti-offshore mining movement was not indicative of a truly capitalist political settlement process, but rather reflected the failure of clientelist actors. Why did they fail? This will be explored below.

This article employs qualitative research, using the comparative method, and uses empirical evidence to identify similarities and differences in the social, political, and economic conditions of Bangka and Belitung (within the context of offshore mining), as well as the implications of these similarities and differences (Chilcote, 2004). Data were collected between 2017 and 2019 through in-depth interviews, participant observation, and a review of secondary sources. Data were subsequently validated using the triangulation method. To answer the research question, data were analysed comparatively.

\section{Tin Mining in Bangka-Belitung: Its History, Dynamics, and Distinctions}

The islands of Bangka and Belitung, which collectively form Bangka-Belitung Province, are Indonesia's largest producers of tin. Almost $90 \%$ of the country's tin originates from these two islands (Hodal,
2012, in Diprose et al., 2020). Historical records indicate that tin mining in BangkaBelitung had begun in the pre-colonial era, with widespread exploitation beginning in the colonial era (Erman, 2007, in Diprose et al., 2020). Colonial extraction companies in Bangka, Belitung, and Singkep were nationalised by the Indonesian government after the country's independence, combining them into one company: PN Timah. In 1976, this company was reorganised to create a state-owned enterprise (PT Timah), which maintained a monopoly over tin production that endured until the fall of the authoritarian Soeharto regime. Owing to this lengthy history, local culture has been strongly influenced by the extraction and trade of tine (Diprose et al., 2020).

As Indonesia democratised following the fall of the authoritarian New Order regime, the authority to manage tin extraction was delegated to local governments and private-sector actors. This decentralisation and liberalisation, which coincided with the creation of Bangka-Belitung Province, resulted in fierce competition for access to tin mining and its profits. Competition occurred between central, provincial, and regency governments; between state actors and private-sector actors; and between state actors and local residents (Zulkarnain, 2005).

Nevertheless, the economic benefits of decentralisation and liberalisation have primarily benefited local actors (Erman, 2007). Tin extraction has become a cornerstone of the local economy. This is especially evident in Bangka, where the state-owned PT Timah operates onshore and offshore mines in conjunction with dozens of local entrepreneurs, and where 
tin smelting furnaces are commonplace. Through taxes, royalties, and exports, tin extraction provides an important economic resource for local governments (Diprose et al., 2020). Indirect benefits are also evident; through their investment activities and their employment of local residents, tin extraction companies have contributed significantly to the provincial economy.

Unfortunately, however, excessive tin mining in Bangka-Belitung has significantly and deleteriously affected local society. Extraction's environmental impact reaches far beyond mines, being felt in the protected forests, rivers, and coasts of the province. At the same time, the aggressive-and even predatorymining economy has resulted in conflict between governments and communities, as well as between miners and non-miners (Erman, 2007). At the same time, smuggling and other black-market activities have proven problematic, and much of Bangka-Belitung's tin exports were mined illegally (interview with activist, December 2018). The rampant practice of illegal mining results in the loss of taxes and royalties, accelerates environmental degradation, promotes the exploitation of child and woman labour, and subjects miners to unsafe environments where workplace health and safety protocols are non-existent.

This discussion has shown that Bangka-Belitung has a long history of tin exploitation, and this has shaped the specific social, political, and economic conditions in which present-day mining occurs. At the same time, however, it is important to note the differences between Bangka and Belitung, which have distinct social, political, and economic conditions that have affected residents' response to tin extraction.

The first key difference lies in the tensions between local residents and PT Timah. In the early 1990s, PT Timah withdrew from Belitung and ceased operations after announcing that the island's tin reserves had been depleted (Diprose et al., 2020). To ameliorate its financial situation, the company downsized most of its local employees (Erman, 2009) without paying adequate compensation. As a result, many of Belitung's residents suddenly lost their livelihood, and their financial difficulties disrupted the local economy. Tensions endured for decades in Belitung, and many local residents directed their hatred and anger at PT Timah (Diprose et al., 2020). In Bangka, meanwhile, tensions between PT Timah and local residents have been temporary and sporadic, occurring (for instance) when residents are driven by falling pepper and rubber prices to supplement their incomes by smuggling tin, thereby leaving them at risk of arrest and detention (Erman, 2007).

The second difference lies in the economic paradox of tin mining. In Belitung, rapid and rampant exploitation resulted in the industrial exploitation of tin deposits becoming economically unviable within ten years. Tin deposits available to artisanal miners were likewise limited (interview with a miner, 2018), and many lost their livelihoods and were forced to seek alternative employment. Tin collectors and sub-collectors, most of whom had access to more capital, migrated to the tourism and the oil palm sectors. Conversely, Bangka-an island three times the size of Belitung-had significantly larger tin deposits. Furthermore, exploitation has not been 
limited to onshore mining, but also involved offshore mining, which has developed rapidly and become a backbone of the industry. As a result, the people of Bangka have not faced the same economic paradox.

The third difference lies in the value chains of post-decentralisation tin exploitation. In Bangka, the Bangka Regency government rapidly seized the momentum of tin deregulation, issuing Local Bylaw No. 2 of 2001 regarding the Issuance of Tin Ore Export Permits and Tin Mining Permits for Local Residents and Local Bylaw No. 21 of 2001 regarding the Implementation of General Mining in Bangka Island. These bylaws stimulated the rise of dozens of local companies, employing approximately 130,000 people (formal employees and artisanal miners) in 2002; these companies were involved in both mining and export activities (Erman, 2009).

However, in June 2002, these export policies were cancelled by the Ministry of Trade, which required that all tin ore be smelted prior to export. This promoted the rise of new tin smelters in Bangka. Owing to their close association with the regent, local entrepreneurs had ready access to permits, and dozens of smelters had been constructed within a decade. These entrepreneurs, in conjunction with the regent, also found a way to sidestep export restrictions; the regent began issuing Permits for Inter-Local Trade (Surat Izin Perdagangan Antar Daerah, SIPAD). Although these permits were claimed to facilitate the smelting of tin in other parts of Indonesia, they were ultimately used to facilitate the smuggling of ore to foreign buyers (Erman, 2009). Through these processes, new businesses emerged that concentrated on mining, smelting, trading, and exporting tin. The rapid and radical response of government officials, in conjunction with local entrepreneurs, resulted in the rapid maturation of the tin value chain in Bangka. This, in turn, stimulated the rise of a local bourgeoisie with significant capital, who worked in conjunction with politicians, officials, bureaucrats, and brokers to achieve a political settlement and prevent conflict.

Conversely, the Belitung Regency government did not issue any radical tin extraction policies immediately after the creation of Bangka-Belitung Province. As such, tin extraction and trade were handled predominantly by local actors (many of whom were working illegally), subcollectors (district-level brokers) and collectors (regency-level brokers). Collectors purchased and amassed tin from the sub-collectors underneath them, then sold this tin to their patrons.

Diprose et al. (2020) have shown that Bangka and Belitung have differed significantly in their response to demands for a sustainable value chain. Stakeholders in Bangka have ignored the Tin Working Group's demands for a sustainable value chain, for fear that such a chain would disrupt the established order. Stakeholders in Belitung, meanwhile, have been more open to sustainable mining discourses.

In conclusion, deep-rooted grudges against PT Timah, the paradoxes of the mining economy, and diverse value chains have all shaped the specific political opportunity structures in Bangka and Belitung. The aforementioned study by Diprose et al. (2020) has reinforced the argument that the islands' specific historical, socio-political, and economic 
contexts have influenced how Bangka and Belitung have approached tin extraction.

This section has provided an introductory overview of the historical context and political/economic dynamics of tin extraction in Bangka-Belitung. These islands' different contexts have implications for local residents' response to offshore mining, resulting in the people of Belitung strongly opposing such mining and the people of Bangka accommodating it. In the following section, the author will provide a brief overview of the resistance in Belitung that has blocked (successfully, as of writing) plans to commence offshore mining. This will be contrasted with the experiences of Bangka, where resistance was sporadic and temporary, and ultimately where residents ultimately failed to block offshore mining.

\section{Extensive Resistance to Offshore Tin Mining in Belitung}

Public opposition to offshore tin mining in East Belitung peaked with a 2,000-member demonstration, which was held in October 2016 on a beach across from a planned offshore mine. Uniquely, this demonstration not only involved a coalition of fishermen, tourism actors, local officials, students, and environmentalists, but was led by two regents: the regents of Belitung and East Belitung. Protestors demanded the withdrawal of suction vessels, ${ }^{2}$ and sought to ensure that Belitung's waters would remain free of offshore mining (Arumingtyas, October 2016).

\footnotetext{
${ }^{2}$ Vessels equipped with the technology necessary to remove underwater materials. In
}

This demonstration, however, did not occur in isolation; it was the culmination of a series of activities oriented towards blocking offshore mining in Belitung. Five years previously, the residents of Belitung had successfully blocked marine dredging intended to facilitate the construction of a tourism resort. Since 2016, large demonstrations had been interspersed with routine creative activities and discussions, as well as efforts to reach local and national media outlets. Using technology, including Facebook and WhatsApp groups, activists were able to frame and mobilise their issues online. At the same time, they allied themselves with local elites, holding demonstrations in front of the regency parliament and seeking audiences with parliamentarians and government officials (interview, 2018). In short, the anti-mining movement in East Belitung began in 2015, grew rapidly, and remains strong today.

Though Fishman (2017) argues that effective social movements most commonly originate from the financially disadvantaged and socio-culturally marginalised, this is not true in East Belitung. Many learned from the experiences of fishermen in Bangka, whose household incomes suffered significantly after the commencement of offshore mining. Before mining began, these fishermen had been able to catch 10 kilogrammes of fish less than a mile from the beach. After mining began, they sometimes had to travel thirty miles for a catch of the same size; this was significantly more dangerous and costly (Kumparan, 2018). Offshore mining was

Bangka, such vessels are widely identified with offshore tin mining. 
seen as causing water pollution, damaging coral, and killing sea life (Kumparan, October 2018). The empirical experiences of Bangka motivated the people of Belitung to promote conservation efforts, thereby protecting the oceans and all life contained within (interview with fisherman, 2018).

Conversely, the people of Bangka were slower and more varied in their response to offshore mining. Some protested; others were more accommodating. Residents' responses were influenced predominantly by their access to tin resources, rather than their concern for the environment. Those who resisted were predominantly fishermen, whose livelihoods were detrimentally affected by water pollution. Those who accepted offshore mining, meanwhile, were mainly fishermen who had become offshore miners (Erman, 2010).

\section{Political Opportunity Structures in Bangka-Belitung: Similar Opportunity Structures, Different Effects}

Tarrow (1996) identifies three main approaches for analysing political opportunity structures: the policy approach, the movement approach, and the state approach. The first two approaches are used primarily in local-level analysis, while the third is most beneficial for international comparison. Seeking to understand how changing formal structures affect the specific dynamics and political opportunities of movements, this article employs a specific opportunity structure approach.

Tarrow's concept of political opportunity structures is not limited to formal structures. It also includes conflict structures and resource-providing alliances
(Kriesi, 1991, in Tarrow, 1996), both concepts that significantly strengthen this article's analysis. Elite fragmentation, as well as movements' ability to exploit said fragmentation by establishing their own alliances, significantly influences their access to political channels and necessary resources. When such features are lacking, movements tend to be weaker.

This article's analysis uses three of the dimensions offered by Tarrow (1994): political access (open/closed), degree of elite fragmentation (fragmented/consolidated), and alliances with elites (existent/non-existent) (Heijden, 2006). These will be defined in detail below.

\section{Political Access}

The fall of the authoritarian Soeharto regime marked a turning point in Indonesian history, being the beginning of the country's democratisation and the momentum for creating political access (Robison \& Hadiz, 2004). Over time, Indonesians became increasingly able to provide input and voice their demands regarding national and sub-national policies (Wahlstrom, 2006). Political channels became increasingly open to collective action and civil society movements, which used these channels to promote media freedom and demand diversity in media ownership. At the same time, dozens of new political parties emerged, and thus Indonesian politics shifted from a three-party system to a multi-party one.

After decentralisation-at least until the passage of Law No. 3 of 2020-laws regarding local governments (including Law No. 22 of 1999; Law No. 32 of 2004; and Law No. 23 of 2014) and oil-and-gas 
resources (Law No. 4 of 2009) provided local governments with the authority to issue and rescind mining permits. This decentralisation significantly transformed the dynamics of local governance, introducing a greater level of independence in the local arena.

Together with the local government's authority in mining matters, the availability of various political channels was a determinant factor in the success of the anti-offshore mining movement in East Belitung. Institutionalised resistance was activists' main channel, and demands were conveyed through such diverse strategies as dialogue with government officials, demonstrations, and media campaigns.

Activists first sought to create dialogue by attending public hearings at the provincial and regency-level parliaments. Second, they sought an audience with the regent; however, as the governor was the final authority in the matter, the regent could only issue a statement. Finally, activists reached out to Susi Pudjiastuti, the Minister of Marine Affairs and Fisheries, and established networks within the national government.

In analysing the political access dimension, it is necessary to consider the state's response to activists' demands. Scholars have identified two common strategies used by states when responding to popular pressure: repression and facilitation. Authoritarian states tend to employ repressive approaches, while democratic nations are normally more facilitatory (Tarrow, 1994). In the case of East Belitung, the regency and provincial governments both employed facilitatory approaches; however, they differed in their level of acceptance.
Also necessary when analysing the political access dimension is answering the question of whether states involve civil society associations as partners in political dialogue (Wahlstrom, 2006). It is apparent that, in the case of East Belitung, the regency and provincial governments were more open and accommodating in their response to civil society movements than in Bangka. Nevertheless, the provincial government still sought to convince the people of Belitung to accept offshore mining (interview with fisherman, December 2018).

Technology should also be considered as an analytical variable, given that technology contributes significantly to civil society movements' ability to effectively network with other movements and convey their demands to the media (Domaradzka, 2018). In the case of East Belitung, the anti-offshore mining movement benefited from technology in several ways. It provided activists with a medium for promoting their agendas, conveying their demands, and disseminating news, as well as access to databases and documents. Social media campaigns contributed significantly to their efforts to create and maintain solidarity amongst the people of Belitung, while online storage facilities and databases enabled them to effectively document their activities.

From this discussion, it may be concluded that open political access was a primary driver of the anti-offshore mining movement's success in East Belitung. Such political access was made possible by intermediation, through which activists were able to consolidate their demands (Heijden, 2006) 


\section{Elite Fragmentation}

It is important to remember that the concept of political opportunity structures, as offered by Tarrow (1996), is not limited to formal structures; it also includes the conflict structures that can be exploited by movements. Conflict can create opportunities, as elites may support movements (by providing resources and political access, for instance) to advance their own interests and undermine their opponents (Tarrow, 1996).

In Bangka-Belitung, elite fragmentation existed at different levels. Within the provincial government, there existed fragmentation between the executive and legislative branches. At the same time, there was conflict between provincial and regency governments. In 2017-2018, during the peak of the conflict, the Governor of Bangka-Belitung was a member of the Gerindra Party, while the speaker of the Bangka-Belitung Parliament was a member of the Democratic Party of Indonesia-Struggle (PDIP)-the leader of the opposition coalition. These parties' disputes were exacerbated by Indonesia's national dynamics, including the rising tensions that followed Jakarta's 2017 gubernatorial election and preceded the country's 2019 national election. The opposition coalition, led by PDIP, openly criticised the governor's policies regarding offshore mining. This coalition also provided activists with the political access they needed to voice their demands (interview with activist, December 2018).

Further fragmentation occurred between the provincial and regency governments. Law No. 23 of 2014 resulted in regency governments' authority in mining matters being divested to the provincial level. As such, offshore mining solely benefited the provincial government (by providing revenue). Regencies, meanwhile, lost both a significant source of revenue as well as a strategic interest in promoting mining. Individual officials, similarly, lost access to the personal profits that illegal mining and smuggling had provided (interview with activist, December 2018).

While the debate over offshore mining was reaching its apogee, Belitung was developing its tourism industry. This sector's interests were often opposed to those of the mining industry, to the point that the environmental degradation caused by offshore mining would prove disastrous to Belitung's efforts to develop a tourism economy. Many miners, who had longestablished mutualistic relationships with local politicians, had already diversified their interests and sought other livelihoods. As the result of regency governments' and local politicians' diminishing interest in mining Belitung, many opposed the provincial government by providing the anti-offshore mining movement with political access and resources, thereby facilitating activists' efforts to voice their demands.

The situation in Bangka, conversely, was different. Elite fragmentation was driven not by pro- and anti-mining discourses, but by questions of access (Erman, 2010). Such fragmentation was most tangible in the years following the fall of the New Order regime, when frictions emerged between parties/coalitions and levels of government (i.e. the provincial government vis-à-vis the Bangka Regency government). These elites allied themselves with entrepreneurs and local residents, thereby creating fragmentation within communities themselves. Lines 
were drawn between miners with different political affiliations, as well as between miners and non-miners (Erman, 2010), without distinguishing between onshore and offshore mining. As no elites were against offshore mining, the anti-offshore mining movement had fewer opportunities to make themselves heard.

Based on the above, it may be concluded that the elites were fragmented on the issue of offshore mining in Belitung, but consolidated in Bangka.

\section{Alliances with Influential Elites}

When politicians and civil society movements share an ideology, they are generally more receptive to establishing an alliance (Wahlstrom, 2006). During these alliances, politicians tend to provide movements with resources and spaces for articulating their demands. In Indonesia, such ideological interests are often secondary to pragmatic ones-i.e., rentseeking and voter support consolidation (Berenschot \& Aspinall, 2019). In East Belitung, the anti-offshore mining movement was able to ally itself with several influential figures, including the Regents of Belitung and East Belitung, members of the East Belitung Parliament, members of the opposition (PDIP), the National Maritime Affairs and Fisheries Institution, and the Ministry of Maritime Affairs and Fisheries (interview with activist, December 2018).

Broadly speaking, elites contributed to the anti-offshore mining movement in East Belitung in three ways: providing resources to activists, creating spaces in which activists could convey their aspirations, and supporting activists' demands in formal decision-making processes. As such, activists' alliances with political elites were foundational for activists' successful opposition to offshore. Activists' alliance with local regents is evidenced in three ways: their official statements of political support, their leadership of demonstrations, and their formal requests that the governor end all suction vessel operations (interview with activist, January 2019). PDIP-which formed the opposition-provided activists with space to voice their aspirations, and ensured that the Coastal and Small Islands Bylaw ultimately provided no space for offshore mining in Belitung. Through their alliance with the Ministry of Maritime Affairs and Fisheries, finally, activists were able to bring the issue of offshore mining to the national level, thereby drawing the attention of a broader range of stakeholders.

As stated by Berenschot and Aspinall (2019), most political elites are driven primarily by electoral interests; economic interests, though secondary, are also significant. Offshore mining was perceived as crucial, and thus it was a hot-button issue in Belitung's executive and legislative elections. Between 2016 and 2018, it was commonplace for politicians-both incumbents and their challengers-to openly reject offshore mining (interview with activist, December 2018). Politicians' electoral interests coincided with activists' goals, and this facilitated the establishment of alliances between them.

Conversely, the anti-offshore mining movement in Bangka was unable to ally itself with influential elites, as opposition to offshore mining was not seen as electorally significant. Rather, elites sought to establish alliances with miners and other supporters of offshore mining (interview 
with activist, December 2018). It may thus be concluded that, while alliances with influential elites existed in Belitung, no such alliances were present in Bangka.

\section{Clientelist Political Settlement in Extraction: Bangka's Success, Belitung's Failure}

Clientelist political settlement is characterised by the paternalistic distribution of political and economic resources, personal compliance mechanisms, and power being wielded by formal and non-formal institutions-often in violation of existing regulations. Clientelist political settlement does not concern itself with the legality and illegality, exclusivity and inclusivity, or justice and injustice of its approach. It prioritises solely the distribution of resources to ensure long-term political stability, as such stability is essential for business development (Khan, 2010).

The liberalisation and deregulation of tin in the early 2000s resulted in widespread political instability and fragmentation in Bangka, as diverse actors competed for access to the tin market and its profits (Erman, 2009). The national government competed with local governments; the provincial government competed with regency governments; governments at all levels competed with communities; and private-sector actors competed with communities (Zulkarnain, 2005). During this period, actors used diverse regulations to legitimise their own interests, and thus all coalitions had to involve government agencies (as those with regulatory authority). The concepts of legality and illegality, thus, were produced within this context of continued contestation (Erman, 2008).

Ultimately, two coalitions dominated public discourse. The first consisted of the Governor of Bangka-Belitung, two political parties (Golkar and the United Development Party), and PT Timah. The second, meanwhile, consisted of the Regent of Bangka, PDIP (which included in its ranks many entrepreneurs of Chinese heritage), the Bangka-Belitung Police, and Hendri Lie's tin conglomerate (Erman, 2007). Each coalition had expansive networks, ranging from the highest to the lowest levels. After Bangka was divided into five regencies, and after authority was divested to local governments through Law No. 4 of 2009, these coalitions fragmented into smaller, stabler ones. Although these coalitions' specific actors changed rapidly, the local bourgeoisie consistently wielded power.

The local bourgeoisie, enriched by the tin sector, were able to coordinate politicians, bureaucrats, and officials from the national to the regency level. Their business networks reached into the transportation, plantation, and accommodation industries; one tin entrepreneur even owned an airline. These entrepreneurs formed a shadow state, one capable of controlling formal institutions, co-opting local communities to ensure their loyalty, and curtail anti-mining activism through clientelist political settlement practices (Erman, 2007).

Even as elites advocated settlement mechanisms that benefited all involved, many in the community remained passive, acting only as the clients of specific patrons. Many sought to maximise their profit, without distinguishing between onshore and offshore mining. As such, 
elites did not concern themselves with changing communities' minds or attempting other settlement approaches. Several mechanisms were used: providing legal protection, providing mining area, and purchasing tin (both legal and illegal) from miners. Patrons also provided social assistance to local residents who lived in poverty (Erman, 2007; Erman, 2010).

The clientelist political settlement practiced in Bangka in the 2000s strongly affected the island's dynamics in subsequent years. Clientelist mechanisms, characterised as exclusive, spoils-driven, and personalised, were again used to control discourse over offshore mining. Again, local communities were co-opted. They were included in the tin value chain, permitted to operate in the area, provided capital loans, and involved in the sale of tin-both legal and illegal (Erman, 2007). Such paternalism divided communities, stemming the rise of consolidated opposition to offshore mining activities. Those movements that did emerge were unorganised, sporadic, and temporary, and thus failed (in many cases) to ensure their demands were heard by the government.

While the local bourgeoisie in Bangka successfully blocked resistance by co- opting local communities, such clientelism was ineffective in Belitung. The failure of clientelist political settlement in Belitung may be attributed to three factors: the absence of local bourgeoisie, the strength of environmental issues, and the rise of tourism as an alternative revenue source.

\section{The Absence of Local Bourgeoisie}

As in Bangka, the tin collectors of Belitung attempted to achieve political settlement by providing legal protection, ensuring access to mining areas, and purchasing tin ore. However, they lacked the power, capital, and networks of their peers in Bangka; Belitung's largest collector was still a client of a collector in Bangka. At this point, it is important to note that the tin trade in Bangka-Belitung follows a clan model. Each clan consists of miners at the bottom, who sell their tin to sub-collectors (at the sub-district level); above these subcollectors are collectors (at the regency level), smelter owners, and exporters. Relationships are paternalistic, with those higher in the hierarchy being the patrons of those below them (Nugraha, 2020). For further detail, see Chart 1 below. 
Figure 1. The Clan Model in Bangka-Belitung
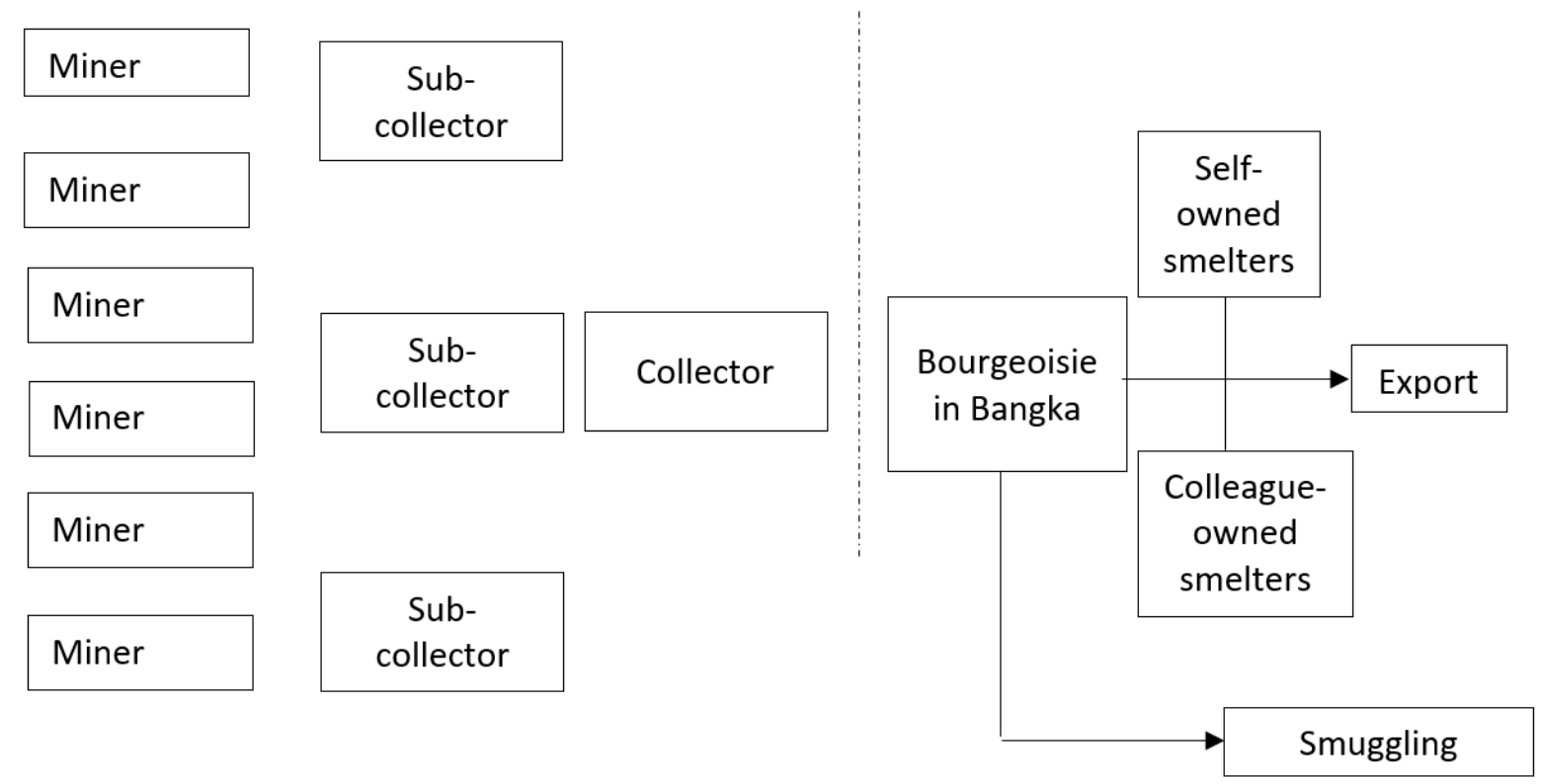

Source: Author's Analysis (2021)

In Bangka, these business relationships are mature and built on a foundation of loyalty. Such loyalty is lacking in Belitung. Miners and subcollectors are willing to sell to whichever collector offers the best price. Weak business ties, consequently, the bourgeoisie in Belitung were unable to coopt local communities or curb anti-mining activities.

\section{Environmental Issues: A Means for Consolidation}

Environmental issues were broadly used by activists in Belitung to justify their opposition to offshore mining. In doing so, they gained access to transnational actors with an interest in promoting sustainable and environmentally friendly extraction techniques (Diprose, et al., 2020). As an issue, "the environment" is universal, and thus able to attract the participation and support of people with diverse interestsincluding those whose livelihoods were not directly affected by offshore mining-such as fishermen and tourism actors (Sholihin, 2019). The following paragraph provides an example of how activists mobilise public support by voicing environmental issues on a local talk show.

Onshore mining is damaging, but the rehabilitation process is not nearly as complicated as offshore mining. Onshore mines can be repurposed, used as new economic resources. But at sea, after the damage has been done, it will last for hundreds of years. The seas cannot be used after being mined (People's Forum against Offshore Mining, 2018)

In such environmental messages, humanity and nature are positioned as two elements of a single whole. When humans harm nature, they will inexorably be affected as well. This may not be immediate; the consequences of human action may only be felt years or decades in the future (Dewi, 2015). Such arguments 
were repeatedly voiced by activists to strengthen their anti-offshore mining message (interview with activist, December 2018).

Buttressing their arguments, activists regularly urged residents to "learn from Bangka's experiences" with offshore mining and the pollution it caused (Kumparan, October 2018). As further empirical evidence of mining's long-term effects, activists noted that Belitung's widespread flooding in 2017 could be traced to its history of tin mining (detik.com, July 2017). Through such environmental messages, activists were able to mobilise the people of Belitung against offshore mining, thereby countering the local bourgeoisie's attempt at clientelist political settlement (Sholihin, 2019).

\section{The Rise of Tourism as an Alternative Economic Resource}

Inexorably tied with Belitung's tourism industry is Laskar Pelangi, a 2008 film adapted from the novel of the same name by Andrea Hirata (a Belitung-born author), which showcased the beauty of the island's beaches even as it explored the issue of social marginalisation. Within four years of the film's release, the tourism industry had grown rapidly, drawing the attention of the local government, private sector, and communities. The national government even included Belitung in its strategic tourism-development program, "Ten New Balis" (Sholihin, 2019)

This rapid and massive response shows that tourism was quickly accepted as a new industry, one unexpected in a region with a lengthy history of tin mining. Its actors quickly imagined a new form of welfare, one that involved not the mining sector but the tourism industry. They recognised that Belitung's natural beauty, particularly its coasts, would be central to developing tourism in the island. As such, they sought to protect Belitung's coasts from the environmental consequences of offshore mining. As one tourism actor, who had also been involved in the anti-mining movement, explained:

Don't say that tourism and mining can occur simultaneously. Look at Bangka. Has its tourism industry developed? Belitung... I'm active in the tourism sector, and [in the future] my great-grandchildren could become involved in tourism. What about mining? After the tin is gone, it's over (local tourism entrepreneur, December 2018).

The above statement implies that offshore mining and (maritime) tourism have contradictory goals. The people of Belitung, disenchanted with tin mining, had identified tourism as having significant potential, and they thus chose to prioritise the development of the sector over further tin exploitation (Sholihin, 2019). This was a third reason for the failure of clientelist political settlement in Belitung.

\section{Discussion and Conclusion}

The above analysis has produced arguments that, in conjunction, answer this article's research question: "Why did the anti-offshore mining movement fail in Bangka, but succeed in East Belitung?" Evidence has shown that, in the extractive industries, political opportunity structures 
and settlements are closely intertwined with historical factors as well as local economic and political dynamics. Environmental issues, long recognised as an external factor, likewise have local dimensions that influence political opportunity structures and settlements-at least to some extent.

This article's greatest contribution to the literature on political opportunity structures in Indonesia lies in its application of the concepts offered by Tarrow (1996) to identify similarities and differences at the sub-national level. This comparative study has found that Bangka and Belitung both provide open political access (to formal structures), but differ in their elite fragmentation (conflict structures) and movements' ability to ally themselves with influential elites.

Approaches that focus solely on formal structures, emphasising open political access, are insufficiently refined for unitary republics such as Indonesia. When the highest authority lies with the central government, local governments lack the power to transform public demands into policy. Using the political channels made available through Indonesia's decentralisation, the people of Belitung and Bangka enjoyed the same political access in voicing their demands. However, the level of acceptance varied; the provincial government was seen as more receptive to the demands of Belitung than those of Bangka.

Combining such a formal approach with one that recognises conflict structures and alliances with influential elites, meanwhile, offers a ready means of understanding how these factors influence movements' success. As Indonesia has decentralised, the political and economic dimensions of its local governments have diverged, a condition shaped by variations in the socio-political configurations of the country's different provinces and regencies. In the case of Bangka-Belitung, these socio-political configurations coincided with geographic separateness, thereby exacerbating elite fragmentation while simultaneously facilitating alliances. Below, Table 1 summarises this study's findings of political opportunity structures at the sub-national level.

Table 1. Different Dimensions of POS, Bangka and Belitung

\begin{tabular}{ccc}
\hline POS Dimension & Bangka & Belitung \\
\hline Political access & Open & Open \\
Elite fragmentation & Consolidated & Fragmented \\
Alliances with influential elites & Not present & Present \\
\hline
\end{tabular}

Source: Author's analysis (2021)

Next, this comparative study of Bangka and Belitung has explored why elites' clientelist political settlement succeeded in one place but failed elsewhere, as well as the implications of this finding for the development of democracy in Indonesia. Just as narrow political settlement successfully curbed conflict and separatism in Riau (Diprose \& Azca, 2020), clientelist political settlement-using both legal and illegal means, with personal and exclusive mechanisms-was effective in safeguarding the extractive industry in Bangka. This study has shown that the skill of tin brokers and collectors (collectively, 
Elites' limited skill was far from the the local bourgeoisie) was a determinant factor in the success and failure of political settlement. In Bangka, the local bourgeoisie successfully blocked opposition to offshore mining. Conversely, in Belitung, the local bourgeoisie were unable to effectively use clientelist political settlement to curtail conflict in East Belitung. only factor, however, Economic and environmental factors also contributed to the failure of clientelist political settlement in Belitung. The strength of environmental issues, in conjunction with the diversification of the local economy, resulted in offshore tin mining being dismissed. Table 2 summarises this article's findings regarding the dynamics of political settlement in Bangka-Belitung

Table 2. Clientelist Political Settlement: Successful in Bangka, Unsuccessful in Belitung

\begin{tabular}{cccc}
\hline Contributing Factor & Bangka & Belitung & Implication \\
\hline Local Bourgeoisie & Successful & Failed & $\begin{array}{c}\text { Failure of Clientelist Political } \\
\text { Settlement in Belitung }\end{array}$ \\
Environmental Issues & Weak & Strong & $\begin{array}{c}\text { Failure of Clientelist Political } \\
\text { Settlement in Belitung }\end{array}$ \\
& & & Failure of Clientelist Political \\
New Economic & Not present & Present & Settlement in Belitung \\
Resources & & & \\
\hline
\end{tabular}

Source: Author's Analysis (2021)

Although clientelist political settlement can help manage conflict, it does not address its substance. In Bangka, although resistance to offshore mining was neither extensive nor institutionalised, the root of the conflict-the contestation between the mining and fishing industrieswent unresolved. Sporadic resistance, primarily involving individuals whose livelihoods depended on fishing, has continued. It is possible that, with an appropriate trigger, such sporadic resistance could develop into a broader movement.

Finally, as shown by the case of Bangka-Belitung, clientelist political settlement can reduce conflict. At the same time, however, this practice restricts civil society movements, thereby fettering democratic development. As such, it would be better to employ a capitalist approach to political settlement (Khan, 2010), one characterised by legal, impersonal, and inclusive mechanisms. This is necessary to ensure that, in the extractive industry, political settlement does not only further the interests of local elites, but also those of the general public. In this manner, public participation in policymaking would increase, thereby positively contributing to the development of Indonesian democracy. 


\section{References}

Aspinall, E. (2011). Democratization and ethnic politics in Indonesia: nine theses. Journal of East Asian Studies, 11(2): 289-319. DOI: 10.1017/S1598240800007190.

Aspinall, E., \& Klinken, G. v. (2011). The state and illegality in Indonesia. Leiden: KITLV Press.

Berenschot, W., \& Aspinall, E. (2019). Democracy for sale: pemilihan umum, klientelisme dan negara di Indonesia. Jakarta: Yayasan Pustaka Obor Indonesia.

Chilcote, R. H. (2004). Teori perbandingan politik: penelusuran paradigma. Jakarta: Raja Grafindo Persada.

Clayton, D. M. (2018). Black Lives Matter and the Civil Rights Movement: a comparative analysis of two social movements in the United States. Journal of Black Studies, 49(5): 1-33. DOI: $10.1177 / 0021934718764099$.

Dewi, S. (2015). Ekofenomenologi: mengurai diesekuilibrium relasi manusia dengan alam. Jakarta: Marjin Kiri.

Della Porta, D. (2013). Democracy and social movements. The Wiley-Blackwell Encyclopedia of Social and Political Movements. Oxford: Blackwell Publishing. DOI: 10.1002/9780470674871.wbespm065.

Diprose, R. (2008). Passing on the challenges or prescribing better management of diversity? Decentralization, power sharing and conflict dynamics in Central Sulawesi, Indonesia. Conflict, Security \& Development, 8(4): 393-425. DOI: 10.1080/14678800802539291.

Diprose, R. \& Azca, M. N. (2020). Conflict management in Indonesia's post-authoritarian democracy: resource contestation, power dynamics and brokerage. Conflict, Security and Development, 20(1): 191-221. DOI: 10.1080/14678802.2019.1705074.

Diprose, R., Kurniawan, N. I., Macdonald, K., \& Winanti, P. S. (2020). Regulating sustainable minerals in electronics supply chains: local power struggle and the hidden costs of global supply chain governance. Review of International Political Economy, 1-27. DOI: 10.1080/09692290.2020.1814844.

Domaradzka, A. (2018). Urban social movements and the right to the city: an introduction to the special issue on urban mobilization. Voluntas, 29: 607-620. DOI: $10.1007 / \mathrm{s} 11266-$ 018-0030-y.

Eisinger, P. (1973). The condition of protest behavior in American cities. American Political Science Review, 67(1): 11-28. DOI: 10.2307/1958525.

Erman, E. (2007). Deregulasi tata niaga timah dan pembuatan negara bayangan lokal: studi kasus Bangka. In G. v. Klinken (ed.), Politik Lokal di Indonesia. Jakarta: Yayasan Obor Indonesia.

Erman, E. (2009). Dari pembentukan kampung ke perkara gelap: menguak sejarah timah Bangka-Belitung, Yogyakarta: Ombak.

Erman, E. (2008). Rethinking legal and illegal economy: A case study of tin mining in Bangka Island. Southeast Asia: History and Culture, 37: 91-111. DOI: 10.5512/sea.2008.37_91. 
Erman, E. (2010). Aktor, akses dan politik lingkungan di pertambangan timah Bangka. Masyarakat Indonesia, 36(2): 71-101. DOI: 10.33019/society.v6i2.70.

Fishman, R. M. (2017). How civil society matters in democratization: setting the boundaries of post-transition political inclusion. Comparative Politics, 49(3): 391-409. DOI: 10.5129/001041517820934294.

Frederiksen, T. (2019). Political settlements, the mining industry and corporate social responsibility in developing countries. The Extractive Industries and Society, 6(1): 162170. DOI: $10.1016 /$ j.exis.2018.07.007.

Gomza, I., \& Zajaczkowski, J. (2019). Black Sun rising: political opportunity structure perceptions and institutionalization of the Azov Movement in post-Euromaidan Ukraine. Nationalities Papers, 47(5): 774-800. DOI: 10.1017/nps.2019.30.

Ibrahim, Haryadi, D., \& Wahyudin, N. (2018). Local fisherman resistance in Kelapa Kampit coastal area toward offshore mining activities. E3S Web of Conferences, 47: 05003. DOI: 10.1051/e3sconf/20184705003.

Indra, C. A. (2014). Implikasi terbitnya regulasi tentang pertimahan terhadap dinamika pertambangan timah inkonvensional di Pulau Bangka. Jurnal Society, 2(1): 26-41. DOI: 10.33019/society.v2i1.47.

Harahap, F. R. (2012). Strategi perlawanan penambang timah rakyat: kasus kecamatan Belinyu. Jurnal Sosiologi Andalas, 12(1): 59-80. Retrieved from http://jurnalsosiologi.fisip.unand.ac.id/index.php/JSA/article/view/22.

Heijden, H. V. D. (1997). Political opportunity structure and the institutionalization of the environmental movement. Environmental Politics, 6(4): 25-50. DOI: $10.1080 / 09644019708414357$.

Heijden, H. V. D. (2006). Globalization, environmental movements, and international political opportunity structure. Organization \& Environment, 19(1): 28-45. DOI: $10.1177 / 1086026605285452$.

Kelsall, T. (2016). Thinking and working with political settlements. ODI Briefing. Retrieved from https://www.odi.org/sites/odi.org.uk/files/odi-assets/publications-opinionfiles/10185.pdf.

Khan, M, H. (2010). Political settlement and the governance of growth-enhancing institutions. Research Paper Series on Governance for Growth. SOAS: University of London. Retrieved from https://eprints.soas.ac.uk/9968/1/Political_Settlements_internet.pdf

Klinken, G. v. (2007). Perang kota kecil: kekerasan komunal dan demokratisasi di Indonesia. Jakarta: Yayasan Pustaka Obor Indonesia.

Manalu, D. (2007). Gerakan sosial dan perubahan kebijakan publik: kasus perlawanan masyarakat Batak vs PT. Inti Indrorayon Utama di Porsea, Sumatera Utara. Jurnal Populasi, 18(1): 27-50. Retrieved from https://jurnal.ugm.ac.id/populasi/article/view/12066. 
McAdam, D. (1996). Conceptual origins, current problems, future directions. In D. McAdam, J. McCarthy, \& M. Zald (eds.). Comparative Perspective on Social Movements (pp. 23-40). Cambridge: Cambridge University Press.

McCarthy, J. F. (2004) Changing to gray: decentralization and the emergence of volatile sociolegal configurations in Central Kalimantan, Indonesia. World Development, 32(7): 11991223. DOI: $10.1016 /$ j.worlddev.2004.02.002.

Meyer, D. S. (2003) Political opportunity and nested institutions. Social Movement Studies, 2(1): 17-35. DOI: 10.1080/1474283032000062549.

Meyer, D, S. (2004). Protest and political opportunities. Annual Review of Sociology, 30: 125145. DOI: 10.1146/annurev.soc.30.012703.110545.

Mosse, D., \& Lewis, D. (2006). Theoretical approaches to brokerage and translation in development. In D. Lewis \& D. Mosse (eds). Development Brokers and Translators: The Ethnography of Aid and Agencies (pp. 1-26). Boulder, CO: Kumarian Press.

Munandar, A. I. (2016). Perilaku harga komoditas timah di pasar bursa komoditas. Jurnal Ilmiah Manajemen dan Bisnis, 2(1): 129-137. Retrieved from http://journal.mercubuana.ac.id/index.php/jimb/article/download/3695/1905.

Nooteboom, G., \& Edwin B. P., de J. (2010). Against 'green development fantasies': resource degradation and the lack of community resistance in the Middle Mahakam Wetlands, East Kalimantan, Indonesia. Asian Journal of Social Science, 38(2): 258-278. DOI: $10.1163 / 156853110 \times 490935$.

Nugraha, A., \& Purwanto, S, A. (2020). Neo-ekstraktivisme tambang timah di Pulau Bangka. Indonesian Journal of Religion and Society, 20(1): 12-22. DOI: 10.36256/ijrs.v2i1.95.

Pratama, S. (2018). Dimensi ekonomi politik dalam konflik tata kelola pertambangan. Jurnal Wacana Politik, 3(1): 40-53. Retrieved from http://jurnal.unpad.ac.id/wacanapolitik/ article/view/16084.

Potter, L. (2009). Oil palm and resistance in West Kalimantan, Indonesia. In D. Caouette \& S. Turner (eds.). Agrarian Angst and Rural Resistance in Contemporary Southeast Asia. New York: Routledge.

Robison, R., \& Hadiz, V. R. (2004). Reorganising power in Indonesia: the politics of oligarchy in the age of markets. New York: Routledge.

Ross, M. L. (2004). What do we know about natural resources and civil war?. Journal of Peace Research, 41(3): 337-356. DOI: 10.1177/0022343304043773.

Sholihin, E. B. (2019). Wacana lingkungan dan gerakan perlawanan offshore tin mining di Belitung Timur. Unpublished thesis, Universitas Gadjah Mada, Yogyakarta.

Situmorang, A. W. (2013). Gerakan sosial teori dan praktik. Yogyakarta: Pustaka Pelajar.

Tarrow, S. (1989). Struggle, politics, and reform: collective action, social movements and cycles of protest. New York: Cornell University Press. 
Tarrow, S. (1996). States and opportunities: the political structuring of social movements. In D. McAdam, J. McCarthy, \& M. Zald (eds.), Comparative Perspective on Social Movements (pp. 41-61). Cambridge: Cambridge University Press.

Tarrow, S. (1998). Power in movement. New York: Cambridge University Press.

Tilly, C. (1978). From mobilization to revolution. Reading, MA: Addison-Wesley.

Wahlstrom, M. \& Peterson, A. (2006). Between the state and the market: expanding the concept of political opportunity structure. Acta Sociologca, 49(4). DOI: $10.1177 / 0001699306071677$.

Ward, M. (2016). Opportunity, resources and threat: explaining local nativist organizing in the United States. Sociological Perspectives, 60(3): 459-478. DOI: $10.1177 / 0731121416655994$.

Winanti, P. S. \& Diprose, R. (2020). Reordering the extractive political settlement: resource nationalism, domestic ownership and transnational bargains in Indonesia. The Extractive Industries and Society, 7(4): 1534-1546. DOI: 10.1016/j.exis.2020.08.015.

Zulkarnain, I., Erman, E., Pudjiastuti, T, N., \& Mulyaningsih, Y. (2005). Konflik di kawasan pertambangan timah bangka belitung: persoalan dan alternatif solusi. Jakarta: LIPI Press.

Zulkarnain, I., Sulaiman, A., \& Harahap, F. R. (2018). Modal sosial bentukan dalam penyelesaian konflik di Bangka Belitung. Jurnal Society, 6(2): 92-99. DOI: 10.33019/society.v6i2.70.

\section{Online Newspaper Articles}

Arumingtyas (2016, 21 October). Laut terancam, warga dan pemerintah Belitung tolak kapal isap. Mongabay. Retrieved from https://www.mongabay.co.id/2016/10/14/lautterancam-warga-dan-pemerintah-belitung-tolak-kapal-isap/.

CNN Indonesia. (2018, 21 October). Pariwisata dongkrak perekonomian dan PAD Belitung. CNN Indonesia. Retrieved from https://www.cnnindonesia.com/gayahidup/20181021181414-269-340218/pariwisata-dongkrak-perekonomian-dan-padbelitung.

Hodal, K. (2012, November 23). Death metal: Tin mining in Indonesia. The Guardian. Retrieved from https://www.theguardian.com/environment/2012/nov/23/tin-mining-indonesiabangka.

Ibrahim, G. M. (2017, 16 July). Banjir landa Belitung dan Belitung Timur, akses jalan putus. Detik.com. Retrieved from https://news.detik.com/berita/d-356234/banjir-landabelitung-dan-belitung-timur-akses-jalan-putus.

Kumparan. (2018, 27 October). Simalakama kilau timah di Laut Bangka. Kumparan.com. Retrieved from https://kumparan.com/kumparanbisnis/simalakama-kilau-timah-di-lautbangka-1540612093580465875/full. 
Radar Bangka. (2011, June 24). 10\% kapal nelayan Bangka jadi TI. Radar Bangka. Retrieved from https://www.radarbangka.co.id/berita/detail/sungailiat/912/10--kapal-nelayanbangka-jadi-ti.html.

Wowbabel Team. (2019, 26 September). Pertambangan timah penyumbang terbesar perekonomian Babel. wowbabel.com. Retrieved from https://wowbabel.com/2019/09/26/pertambangan-timah-penyumbang-terbesarperekonomian-babel. 